\title{
Sunk Costs Effect: Does Theoretical Knowledge Affects Students' Decision Process?
}

\author{
Suliani Rover ${ }^{\dagger}$ \\ University of São Paulo \\ Artur Filipe Ewald Wuerges ${ }^{\Omega}$ \\ Federal University of Santa Catarina \\ Eduardo Cardeal Tomazzia ${ }^{\Psi}$ \\ Federal University of Santa Catarina \\ José Alonso Borba ${ }^{¥}$ \\ Federal University of Santa Catarina
}

\begin{abstract}
The sunk cost is defined as a greater disposition to continue an endeavor, once an investment in money, effort or time has been made. According to economic theory, however, these past expenses should not be taken into consideration, as they cannot be recovered. The objective of this study is to investigate if the student from undergraduate courses in the area of business is less susceptible to the sunk costs effect than students from other areas. Five hundred and twenty eight questionnaires were applied on students of nine undergraduate courses of three universities of Santa Catarina. The results confirm the relevance of the cognitive bias caused by sunk costs, as they indicate a lower probability of choosing the right answer when these involve sunk costs in the decisions. The assumption that the students from the business area are less affected by this bias was not confirmed.
\end{abstract}

Key words: Sunk costs; decision process, behavioral finance.

Received in 30/06/2008; revised in 10/12/2008; accept in 18/03/2009.

\footnotetext{
Corresponding authors:

${ }^{\dagger}$ University of São Paulo

Rua Jornalista Tito Carvalho, 101,

Carvoeira

Florianópolis SC - Brazil -

CEP:88040-480

Tel.: (48)9968325

email:sulianirover@yahoo.com.br
}

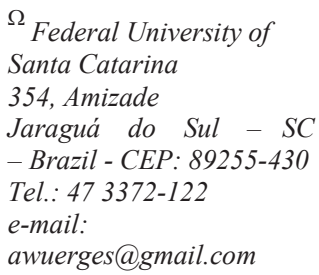

$\Omega$ Federal University of Santa Catarina

354. Amizade

Jaraguá do Sul - SC

- Brazil - CEP: 89255-430

Tel.: 47 3372-122

e-mail:

awuerges@gmail.com

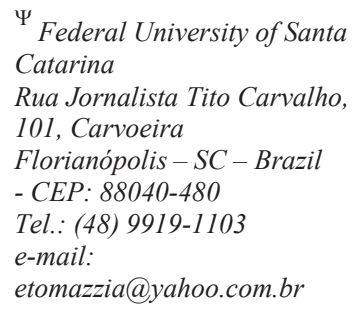

${ }^{\Psi}$ Federal University of Santa Catarina Rua Jornalista Tito Carvalho, 101, Carvoeira Florianópolis - SC - Brazil - CEP: 88040-480 Tel.: (48) 9919-1103 e-mail: etomazzia@yahoo.com.br

\author{
${ }^{¥}$ Federal University of Santa \\ Catarina \\ PPGC-UFSC, Trindade, - \\ Cx.Postal 476 \\ Florianópolis, $S C-$ Brazil \\ - CEP 88040-900 \\ Tel: (48)99683251 \\ e-mail:ppgc@cse.ufsc.br
}

Editor's note: This paper was accepted by Antonio Lopo Martinez. 


\section{INTRODUÇÃO}

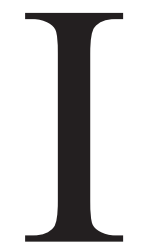

$\mathrm{n}$ various decision problems, one notices a difference between the behavior observed and the advisable decisions. Raiffa (1968) distinguishes in descriptive theory, which is concerned with showing how persons effectively take decisions, and prescriptive theory, which indicates the best decision to be taken in a specific situation- that is, that which maximizes the utility expected. It is expected that both coincide in the majority of cases- i.e., persons really take decisions that maximize the utility expected. What has been observed, however, is that this does not always occur (BAKER; NOFSINGER, 2002; KAHNEMAN, 2003).

Kahneman (2003) explains that cognition can be divided into three systems: perception, intuition and reasoning. The latter two are called, respectively, System I and System II. The demand on each of these systems will depend on the nature of the task being performed. In the case of a financial decision, people very often end up using intuition as a way of reducing its complexity and speeding it up. This commonly occurs through the application of heuristic principles (TVERSKY; KAHNEMAN, 1974).

These heuristic principles are not incorrect by nature. In fact, they are normally useful, by permitting that decisions be taken based on incomplete information, and can also be the expression of an accumulated experience in a certain activity. The problem lies on the biases which occur when heuristics causes a systematic deviation from the expected (or rational) answer. One of these phenomena is the sunk costs effect.

The sunk costs effect is defined as a greater disposition to continue an endeavor once an investment in money, effort or time has been made (ARKES; BLUMER, 1985). According to economic theory, however, these past expenses should not be taken into account, as they cannot be recovered, independently from the decision that is taken.

Therefore, the phenomena analyzed by behavioral finance - including the sunk cost effect - originate from the very architecture of human cognition, which privileges intuitive, quick and automated thought. Consequently, sometimes an inappropriate decision ends up being taken, without System II being enabled to correct it.

In previous research, it has already been determined empirically the occurrence of the sunk cost effect (ARKES; BLUMER, 1985; DOMINGOS; SOUZA; SILVA, 2007; MURCIA; BORBA, 2006; TAN; YATES, 1995). There are different variables that influence the susceptibility of a person to this phenomenon. One of them is the monetary value involved, others are not yet clearly defined. One of these possible variables, contemplated in this research, is the existence of theoretical knowledge on the irrelevance of expenses made.

The objective of this study is to investigate if the student of undergraduate courses in the business area is less susceptible to the sunk cost effect than students in other areas. In this study, are characterized as business area courses in Administration, Accounting, Economics and Production Engineering, because they offer disciplines related to finance and to economic assessment of projects, and other areas courses in Computing, Law, Physics, Mathematics and Psychology. Moreover, characteristics such as gender and age influence the decision process involving the sunk cost effect.

The results of this research can serve to indicate if further education is being effective in guiding its students to the effect of avoiding the consideration of costs based on their investment decisions. Or, eventually, serving as a sign of the impossibility of teaching a person not to let herself be influenced by this effect - in this case, the sunk cost phenomenon would be intrinsically connected to the intuitive system (System I) of cognition. 
Moreover, this research has its relevance by the fact of contributing to the development of experimental research in accounting and behavioral finance. This field of research has its importance precisely by the fact of the decisions taken in practice not always corresponding to those prescribed by theory.

\section{THEORETICAL REFERENTIAL}

\subsection{Sunk Cost Effect}

The sunk cost effect (costs sunk, lost or irrecoverable) is one of the cases in which the behavior effectively observed differs from theoretical prescription. Thaler (1980) explains that the payment for an asset or service increases the probability of this asset being used, ceteris paribus. When a person buys a ticket to a soccer match, the probability that it will go the match is higher than if it had received the same ticket as a gift. But, according to economic theory, only incremental costs and benefits should be taken into consideration in decision making.

Thus, the fact of a ticket having been paid or not should be irrelevant. In an organization, individuals can commit themselves to a certain project and, even after its failure being evident, continue trying to find facts that show that they have taken the correct decision (MCELHINNEY; PROCTOR, 2005). This occurs due to social pressure, since people feel that they must justify their decisions to their colleagues, and to abandon the project would be seen as a sign of weakness and lack of leadership. Organizational inertia also plays its role in the continuity of projects with bad perspectives. These factors cause there to be a growing commitment to an inefficient line of action (entrapment).

Similarly, Hirshleifer (2001) suggests that the sunk cost effect occurs as part of a mechanism whose objective is to cause people to think that they are more skillful decision makers than they actually are. By insisting on a decision, which subsequently proved incorrect, one avoids recognizing an error. This bias ends up providing psychological comfort, but at the expense of financial loss.

The sunk cost effect does not lead to additional investment in projects with lower value than this investment, but also the abandonment of projects which have superior value to the investment necessary to complete it (HEATH, 1995).

This phenomenon is explained by mental accounting: people normally define a mental budget for each project, and upon giving them up when the total value invested exceeds this budget - even when the additional investment is lower than expected from the project. Very often, this budget corresponds to the return expected - that is, one adopts the rule that the return must never be lower than the total investment.

In addition to mental accounting, one can consider this effect as resulting from the application of heuristics in decision making. This idea is defended by Arkes and Ayton (1999), who observe that inferior animals are less susceptible to sunk cost effect.

Animals such as ducks, blackbirds (a bird typical from the Iberian Peninsula) and domestic rats are used to adjusting their efforts by taking into account future benefits, and not past (and irrecoverable) investments. For these authors, the sunk cost effect is an incorrect generalization of aversion to waste (present only in adult human beings). This rule (waste not, want not) is normally useful, but it can also lead to errors. For example, as small children and animals do not have the capacity to apply abstract rules to their decisions and also are not obliged to justify the waste resulting from their decisions, they end up less susceptible to the sunk cost effect. 
Confirming this hypothesis, Webley and Plaisier (1997) presented to a group of children the following hypothetical situation: in a walk in the park, she received a one pound and a fifty pence coin from her parents. After a stroll, she decided to go on the carousel (at the cost of 50 pence), but she lost her ticket before managing to go on the toy. She needed to decide, then, if she would use the one pound coin to buy another ticket. Among children between 5 and 6 years old, $80 \%$ decided to buy another ticket, among those between 11 and 12 , only $20 \%$ took this decision. In a similar experiment made with adults by Tversky and Kahneman (1981), 46\% of participants decided to buy another ticket (in this case, for the theater).

Thus, one can conclude that the sunk cost effect does not necessarily results from limited rationality inherent to the human condition - on the contrary, it can derive precisely for our high capacity of abstraction.

Evidently, this does not mean that a person can avoid this error. It is also possible to explain the sunk cost effect through Prospect Theory (ARKES; BLUMER, 1985; SCHAUBROECK; DAVIS, 1994), which was initially proposed to explain why persons are used to violating the presuppositions of modern finance in certain situations. With the sunk cost effect, it is a violation of the presupposition of maximization of the utility expected, Prospect Theory can be useful in understanding this phenomenon.

\subsection{Prospect Theory}

One knows that decision makers are used to violating the axioms of the Expected Utility Theory. This violations can occur randomly, but sometimes they occur systematically (BAKER; NOFSINGER, 2002). One of the first researches to reveal these systematic biases and perhaps the best known - is that of Maurice Allais (1953). His was followed by others, such as those of Tversky and Kahneman (1974).

Despite the relevance of the Expected Utility Theory as a normative and prescriptive theory of decision making, it was soon clear that it was not possible to describe the decision process realistically without taking into consideration the emotions and feelings that people face in these cases (KAHNEMAN, 2003). To resolve this problem, Kahneman and Tversky (1979) proposed an alternative model to analyze decision making under risk, called Prospect Theory.

Prospect Theory describes the various stages and principles of the decision process under risk, in addition to presenting the functions that relate the objective data (monetary values and probabilities) to their subjective perceptions. These functions recognize the fact that a same financial gain may have, depending on circumstances, different impacts on the same person.

According to Prospect Theory, an individual analyzes his financial situation based on his total wealth. The utility perceived depends on gains and losses, that is, on changes in wealth. Monetary gains and losses are filtered by a value function, showed on Figure 1 . The function is concave for gains and convex for losses, so that one intuited that the marginal value is diminishing in both cases. Moreover, it is not continuous in the point of reference (i.e., the point where the value is zero), as losses are felt more intensely than gains of the same value (in module). 


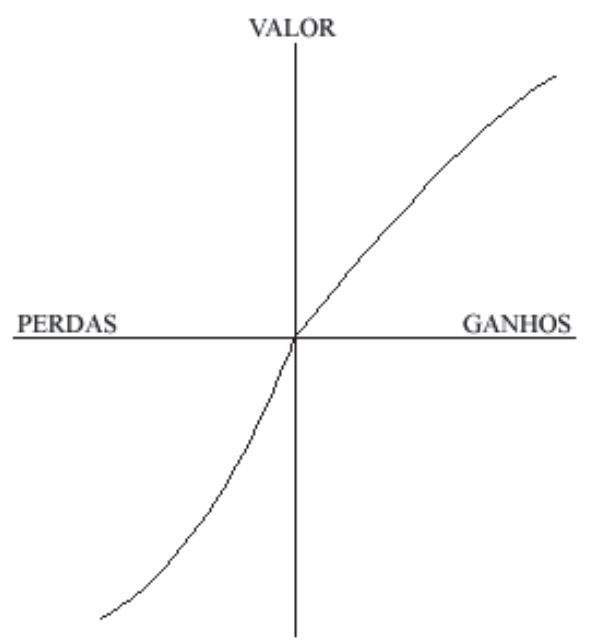

Figure 1 - Value function

The explanation that Prospect Theory presents to the sunk cost effect originates from the observation that when a person suffers a loss, the point (or value) or reference takes some time to be updated. The person does not assimilate the loss immediately and, upon taking the second decision - to continue investing or abandoning the project, for example - the results of the first decision are taken into consideration even if this disagrees with normative theory (ZEELENBERG; DIJK, 1997).

When a person is in its point of reference, a value loss $x$ will be more significant than a loss of the same value when the person has already suffered a considerable loss. The case of sunk costs is precisely a situation where the person is at negative value point.

An additional low will not be very relevant, as the marginal value of these losses is increasingly lower; in compensation, an eventual gain will be very significant. Consequently, the person ends up preferring to take a risky decision- such as continuing to invest in a bad project - to accepting the loss that in fact has occurred.

An example of this occurs when an administrator must decide if he will invest in resources in the construction of a plant.

If he has already authorized a considerable expense, he will be at a negative point of the value function, being more propense to the risk that he would be if he had not yet made any investment.

This phenomenon occurs in situations where the possibility of recovering losses (or the investment already made) is to continue investing in the project. In real situations, frequently one has other investment alternatives. In these cases, the preference is normally for the less risky project available (SCHAUBROECK; DAVIS, 1994).

Another characteristic of the decision process included in Prospect Theory which helps explain the sunk cost phenomenon is called the certainty effect: people normally prefer a result considered certain than an uncertain one, even if this has a higher expected value. This is valid both for gains and for losses, so that a person normally prefers assuming a great risk in exchange for a small possibility of recovering its losses (ARKES; BLUMER, 1985; SCHAUBROECK; DAVIS, 1994). 


\subsection{Similar Studies}

The seminal work regarding the investigation of the sunk cost effects in decision making if of Arkes and Blumer (1985). The authors affirmed that the sunk costs are represented by the trend investors have in not accepting losses and thus not recognizing that they made a mistake. This situation leads to one of the greatest financial errors that an investor can make, i.e., to invest more and more resources in an attempt to recover the former investment that was badly made.

A questionnaire with questions similar to those made by Arkes and Blumer was also applied to students of two Singapore universities (TAN; YATES, 1995). The objective of the study was to investigate the hypothesis that the students of the sunk cost effect exposed because they had never become aware of the normative principles that establish its irrelevance. The respondents were divided into two groups, one formed by students with knowledge of management accounting and another by students of arts, engineering, science and computing. The questionnaire consisted in two hypothetical problems, whereas one of them referred to a choice between two trips to different locations, and another asked the student to make an investment decision for a company. As the students with knowledge of accounting made decisions closer to normative principles in the second case, one reached the conclusion that the occurrence of the sunk cost effect depends on the nature or context of the problem.

In Brazil, three similar studies were analyzed. One study was conducted in the Federal University of Santa Catarina (MURCIA; BORBA, 2006), with students of the courses in Administration, Accounting and Economics, which were studying subjects of cost accounting or management accounting. One identified a substantial influence of sunk costs on the decision process of the students in four of the five scenarios of the decision presented.

Another research conducted by Domingos, Souza and Silva (2007), sought to identify if the information of the value invested in a certain project (lost cost) has influence in decision-making. From questionnaires applied to some students of the courses in Administration, Accounting, Economics and Statistics, one verified that the evidencing of the lost value does not influence decision-making.

In a third research, Silva and Domingos (2008) reached a different conclusion. In a study also with university students, the presence of irrational insistence in connection with the financial amount already invested is verified. The same phenomenon occurs when $50 \%$ or $90 \%$ of the project has been completed.

In another study based on decision scenarios, one notices that fidelity programs can be more efficient when they charge a rate from their members (JANG; MATTILA; BAI, 2007). The customers struggle not to frequent a new restaurant after having paid a small rate to be members of another - even though the first establishment if of superior quality. This means that the sunk cost effect can have practical implications on strategies adopted by companies, especially in marketing.

\section{METHODOLOGY}

The research was based on the application of questionnaires with closed questions, each of them presenting a different scenario and requesting that the student took a decision. First, four decision-making scenarios were taken, and from then on, from each of these scenarios, two questions were created: one of them involving sunk costs, and the other not. 
With the exception of the presence or not of past costs, one sought to maintain each pair of questions as similar as possible, so that any significant difference among the averages of the responses of the two questions is caused by the sunk cost effect.

Each of the four questions formulated presented to respondents a different scenario, involving different values and incentives. The first question requests that the individual decide if he will sell a car or not, which has a value (monetary and symbolic) significant for the majority of persons. Another question presents a situation closer to those faced by professionals of the business area, involving the decision to invest or not in a research and development project. This question investigates if the business students are less influenced by the sunk costs in a scenario closer to the content taught in the classroom. There is also a question which presents a more banal case and everyday case, involving the decision of continuing or not watching a film. One also created a question involving a trip, in which the respondent should choose between two travel packages with different destinations.

The eight questions were divided into two questionnaires (A and B), so that each of them presented two questions with sunk costs, and two without. The questionnaires were applied so that approximately half of the participants in the research answered questionnaire $\mathrm{A}$ and the other half, questionnaire $\mathrm{B}$. The research also included a pre-test, conducted with 20 students of a university contemplated in a study. It should be stressed that no financial incentive conditioned the participation of the respondents. Prior to filling the questionnaire, the due instructions were given, without identifying the theme researched not to influence the answers of the individuals.

The study sample is intentional and not probabilistic. The field research was conducted during the months of September to November 2007, with 528 undergraduate who were between the fifth and tenth semester of courses in Administration, Computing, Accounting, Law, Economics, Production Engineering, Physics, Mathematics and Psychology. The research was conducted with the students of three universities of Santa Catarina, one public and two private.

It is highlighted that from the 528 questionnaires answered, 20 were disposed of for being incomplete. Thus, 248 students answered questionnaire A and 260 questionnaire B. The analysis of the results was performed using the econometric software Eviews 5.0.

The chosen methodology presents quite a relevant limitation, the students were physically separated into two groups to answer the questionnaires. Therefore, there is a possibility that a change of information occurred among the students. If a certain group has noticed that there are two different questionnaires, the answers may have been biased, as the differences among questions would be evident and consequently it would be easier for the student to deduce which was the most appropriate answer. On the other hand, as the two questionnaires were distributed randomly, the fact of somebody simply copying an answer from another person does not have greater implications - since this behavior would occur randomly.

\subsection{Average Equality Test}

To test the sunk cost effects in the average of getting questions right, a test was conducted of the hypothesis of equality of average among the subgroups of right answers of the questions with and without the sunk costs. The average of the series in question, a dummy that indicates if the answer was correctly answered, is equivalent to the proportion of right answers and therefore the $\mathrm{H}_{0}$ of the test is: the proportion of right answers in the questions with the presence of sunk costs in the decision-making is equal to the same proportion in the equivalent questions without the sunk costs. 
The test is based on variance analysis (ANOVA) of the simple factor among subgroups. The principle of the test is that the subgroups have the same average, then, the variability among the averages of samples must be equal to the variability among the subgroups. Formally, the test is described as:

$$
F=\frac{S S_{B} /(G-1)}{S S_{W} /(N-G)} \text {, where } S S \text { is the sum of the deviations of average to the }
$$

unrestricted square (from the total of the sample), $S S_{W}$ is the sum of the deviations of the average to the unrestricted square (of the subgroup analyzed, in the case with the presence of sunk costs), $G$ is the number of groups and $N$ the number of observations. The t test can also be calculated by the square toot of statistic $F$, with a degree of freedom for the case of only two subgroups.

\subsection{Logit Model}

The regression models of a qualitative nature serve to assess the influence of other variables, qualitative or quantitative, in a qualitative regression. The logit model is based on the probability calculation as a function of the accumulated distribution:

$$
P_{i}=E\left(Y=1 \mid X_{i}\right)=\frac{1}{\left.1+e^{-\left(\beta_{1}+\beta_{2} X\right.}\right)}, \text { where } P_{i} \text { is the probability of } Y \text { being } 1 \text {, given } X_{i}
$$

The latter, however, is not the final form of the model, which transforms it into a probability test:

$$
L_{i}=\ln \left(\begin{array}{c}
P \\
1-P
\end{array}\right)=\beta_{1}+\beta_{2} X_{i}, \text { where } L_{i} \text { is the ratio of the probability. }
$$

For qualtitative $\mathrm{X}$ variables, which is the case of the study, the calculation of the probability differential $\left(D P_{i}\right)$, in percentage is as follows (Gujarati, 2000):

$$
D P_{i}=\left[\operatorname{anti} \log \left(/ \beta_{2} /\right)-1\right] \times 100
$$

The variable that one is trying to evaluate, in this study, is the probability differential of getting questions of financial decisions right, given the influence of the sunk costs. The logit models are used for two specific purposes: (a) how an alternative to the test of equality of the average, calculating the differential in the probability of getting questions right, when there are sunk costs in the problem; (b) to test if the undergraduate students of courses in the business are is less susceptible to the sunk costs effect than the students of other areas, as well as the influence of other characteristics (gender and age group) of the respondents. This test was only conducted for problems where the significance of sunk costs was confirmed in the average of questions got right.

\section{ANALYSIS OF THE RESULTS}

This section present the questions applied, with the right answers underlined, the descriptive statistics and the tests taken. 


\begin{tabular}{|c|c|}
\hline Questionnaire A - With Sunk Costs & Questionnaire B - Without Sunk Costs \\
\hline $\begin{array}{l}\text { Suppose that you live far away from the university } \\
\text { where you study and spent with bus fares, } \\
\text { approximately R } \$ 200,00 \text { per month. One day, you } \\
\text { saw the advertisement of a car dealer in connection } \\
\text { with the sale of second hand vehicles with } \\
\text { promotional prices and decided to buy a car. Using } \\
\text { the money you saved for some time, you bought a } \\
\text { vehicle for R } \$ 8,000.00 \text { cash. In the beginning the } \\
\text { vehicle worked perfectly, but after five months it } \\
\text { started to present certain problems, causing you to } \\
\text { spend monthly with maintenance R } \$ 300.00 \text {. You } \\
\text { can no longer return the vehicle and you won't be } \\
\text { able to sell it for the value at which you bought it. } \\
\text { The owner of the concessionaire proposes buying } \\
\text { the car for } R \$ 4,000,00 \text {. Would you sell the car to } \\
\text { the car dealer? }\end{array}$ & $\begin{array}{l}\text { Suppose that you live far away from the university } \\
\text { where you study and spent on bus fares } \\
\text { approximately R } \$ 200.00 \text { per month. Five months } \\
\text { later you bought a raffle and was awarded a second } \\
\text { hand vehicle in the amount of } \$ 8,000.00 \text {. } \\
\text { Recently, you noticed that the vehicle requires } \\
\text { monthly maintenance of } R \$ 300.00 \text {. By putting the } \\
\text { car up for sale, you obtain as the best proposal } R \$ \\
4,000.00 \text {. Would you sell the car? }\end{array}$ \\
\hline $\begin{array}{lll}\text { Yes } & \text { No } & \\
& 46.77 \% & 53.33 \%\end{array}$ & $\begin{array}{l}\text { No } \\
51,53 \%\end{array}$ \\
\hline
\end{tabular}

\section{Chart 1: First scenario questions}

The questionnaire with sunk costs presented the highest percentage of wrong answers (No). But the equality of average test indicated that there was no significant difference between the proportion of right answers, with the probability of error, by rejecting the null hypothesis of tests $t$ and $F$ in $28.39 \%$.

Table 1: Average equality test - scenario 1

\begin{tabular}{l|l|l|l}
\hline \multicolumn{1}{c|}{ Test } & \multicolumn{1}{c|}{ Value } & \multicolumn{1}{c}{ Probability } \\
\hline Test t & 1.072747 & 0.2839 \\
Statistic F Anova & 1.150787 & Average/Proportion & Standard deviation \\
\hline Questionnaire & Quantity & 0.515385 & 0.500727 \\
W/o Sunk Costs & 260 & 0.467742 & 0.499967 \\
With Sunk costs & 248 & 0.492126 & 0.500431 \\
Total & 508 & & \\
\hline
\end{tabular}

As an alternative method, the logit model confirmed that the non-relevance of the statistic of the presence of sunk costs on the index of getting questions right, as demonstrated on Table 2.

Table 2: Logit regression - scenario 1

\begin{tabular}{l|l|l|l|l}
\hline \multicolumn{1}{c|}{ Variable } & \multicolumn{1}{c|}{ Coefficient } & \multicolumn{1}{c|}{ Std. Error } & \multicolumn{1}{c}{ z-Statistic } & \multicolumn{1}{c}{ Prob. } \\
\hline SUNKCOSTS & -0.190770 & 0.177752 & -1.073237 & 0.2832 \\
C & 0.061558 & 0.124093 & 0.496061 & 0.6199 \\
\hline Mean dependent var & 0.492126 & S.D. dependent var & 0.500431 \\
S.E. of regression & 0.500356 & Avg. Log likelihood & -0.691888 \\
Sum squared resid & 126.6804 & McFadden R-squared & 0.001638 \\
Log likelihood & -351.4792 & LR statistic (12 df) & 1.153179 \\
Restr. log likelihood & -352.0558 & Probability (LR stat) & 0.282885 \\
\hline
\end{tabular}


Table 2 presents the problems of questionnaire A (without sunk costs) and of questionnaire B (with costs), involving the decision to choose among one of the travel destinations.

\begin{tabular}{|c|c|}
\hline Questionnaire A - Without Sunk Costs & Questionnaire B - With Sunk Costs \\
\hline $\begin{array}{l}\text { You are planning your end of the year holidays. } \\
\text { Looking at the suggestions of a travel agency you } \\
\text { became interested in Boa Viagem beach, in Recife. } \\
\text { However, the money that you saved was less than } \\
\text { the cost of the trip. Thus, you ended up buying, for } \\
\text { R\$ } 500.00 \text {, a travel package to spend a weekend in } \\
\text { Fortaleza, Ceará. Shortly afterwards, you won a trip, } \\
\text { for the same date, with all expenses paid to spend a } \\
\text { weekend in a hotel on Boa Viagem beach, Recife. } \\
\text { You call the agency where you bought the package, } \\
\text { and they tell you that they can refund you R\$ } \\
500.00 \text {, but that it is not possible to rebook the trip. } \\
\text { You have to choose between the two destinations: } \\
\text { Fortaleza or Recife. Which would you choose? } \\
\text { Boa Viagem - Recife Fortaleza - Ceará }\end{array}$ & $\begin{array}{l}\text { You are planning your end of the year holidays. } \\
\text { Looking at the suggestions of a travel agency you } \\
\text { became interested in Boa Viagem beach, Recife. } \\
\text { However, the money you have saved was less than } \\
\text { the cost of the trip. Thus, you ended up buying, for } \\
\mathrm{R} \$ 500.00 \text {, a travel package to spend the weekend in } \\
\text { Fortaleza, Ceará (without possibility of getting a } \\
\text { refund and rebooking the trip for another date). } \\
\text { Shortly afterwards, you won a trip, for the same } \\
\text { date, with all expenses paid to spend a weekend in a } \\
\text { hotel on Boa Viagem beach, Recife. You have to } \\
\text { choose between the two destinations: Fortaleza or } \\
\text { Recife. Which would you choose? }\end{array}$ \\
\hline $81.15 \%$ & $\begin{array}{rr}\text { Boa Viagem - Recife } & \text { Fortaleza - Ceará } \\
88.71 \% & 11.29 \%\end{array}$ \\
\hline
\end{tabular}

\section{Chart 2: Second scenario questions}

The level of getting the question right for the second scenario followed the expected, with a greater proportion of right questions without the presence of sunk costs. The mean equality test rejected the null hypothesis of non relevance of this fact by tests $t$ and $F$.

Table 3: Mean equality tests -scenario 2

\begin{tabular}{l|l|l|l}
\hline \multicolumn{1}{c|}{ Test } & \multicolumn{2}{c}{ Value } & \multicolumn{1}{c}{ Probability } \\
\hline Test t & 2,382364 & 0,0176 \\
Statistic F Anova & 5,675659 & Mean/Proportion & 0,0176 \\
\hline Questionnaire & Quantity & 0,887097 & Standard deviation \\
\hline Without Sunk Costs & 248 & 0,811538 & 0,317114 \\
With Sunk Costs & 260 & 0,848425 & 0,391835 \\
Total & 508 & 0,358962 \\
\hline
\end{tabular}

The logit model confirms the result of the previous tests. The angular coefficient is negative and significant, and indicates a differential of less $82.46 \%$ in the probability of getting the question right when sunk costs are involved.

Table 4: Logit regression - scenario 2

\begin{tabular}{l|l|l|l|l}
\hline \multicolumn{1}{c|}{ Variable } & \multicolumn{1}{c|}{ Coefficient } & \multicolumn{1}{c}{ Std. Error } & \multicolumn{1}{c}{ z-Statistic } & \multicolumn{1}{c}{ Prob. } \\
\hline SUNKCOSTS & -0.601385 & 0.255748 & -2.351472 & 0.0187 \\
C & 2.061423 & 0.200648 & 10.27381 & 0.0000 \\
\hline Mean dependent var & 0.848425 & S.D. dependent var & 0.358962 \\
S.E. of regression & 0.357318 & Avg. Log likelihood & -0.419816 \\
Sum squared resid & 64.60409 & McFadden R-squared & 0.013199 \\
Log likelihood & -213.2665 & LR statistic (12 df) & 5.704930 \\
Restr. Log likelihood & -216.1190 & Probability (LR stat) & 0.016917 \\
\hline
\end{tabular}


Once the general effect of the sunk costs was confirmed, the logit model was tested with the right answers to the questions, which involved the sunk costs as dependent variable, and important characteristics of the interviewees with qualitative explanatory variables.

Table 5: Logit regression - scenario 2 with sunk costs

\begin{tabular}{l|l|l|l|l}
\hline \multicolumn{1}{c|}{ Variable } & \multicolumn{1}{c|}{ Coefficient } & \multicolumn{1}{c|}{ Std. Error } & \multicolumn{1}{c}{ z-Statistic } & \multicolumn{1}{c}{ Prob. } \\
\hline MAN & 0.022187 & 0.189108 & 0.117326 & 0.9066 \\
LAW & -0.229065 & 0.291154 & -0.786749 & 0.4314 \\
COMPUTING & -0.353146 & 0.645633 & -0.546977 & 0.5844 \\
PHYSICS & 0.097599 & 0.342321 & 0.285109 & 0.7756 \\
MATHEMATICS & -0.315089 & 0.460790 & -0.683801 & 0.4941 \\
PSYCHOLOGY & -0.159779 & 0.307318 & -0.519914 & 0.6031 \\
AGE25TO30 & 0.151943 & 0.232348 & 0.653945 & 0.5131 \\
AGE ABOVE30 & -0.658251 & 0.351133 & -1.874647 & 0.0608 \\
C & -0.270699 & 0.159079 & -1.701661 & 0.0888 \\
\hline Mean dependent var & 0.415354 & S.D. dependent var & 0.493269 \\
S.E. of regression & 0.494309 & Avg. log likelihood & -0.672752 \\
Sum squared resid & 121.9262 & McFadden R-squared & 0.008834 \\
Log likelihood & -341.7582 & LR statistic (8 df) & 6.091690 \\
Restr. log likelihood & -344.8041 & Probability (LR stat) & & 0.636962 \\
\hline
\end{tabular}

The differential of the courses was tested based on the courses considered connected to business, which one supposes, have subjects that deal with sunk costs. These were: Accounting, Economics, Administration and Production Engineering. The results were not significant for any of the courses, whereas, even so, the majority of them (with the exception of Physics) showed a negativesign of response.

With respect to other differences, the gender also did not present a significant angular coefficient, whereas the probability sign when the respondent is a man was slightly positive.

As far as age is concerned, the range above 30 years presented a significant differential of $93.14 \%$ lower probability of getting the question right involving sunk costs in relation to ranges with less than 25 years. The range between 25 and 30 years old presented a non-significant positive result.

\begin{tabular}{|c|c|}
\hline Questionnaire A - Without Sunk Costs & Questionnaire B - With Sunk Costs \\
\hline $\begin{array}{l}\text { Suppose you are the director of "Genérica } \\
\text { Telecomunicações S./A.", a company which develops } \\
\text { and produces cell phones. The engineering department } \\
\text { presented a proposal to develop a new cell phone, } \\
\text { which has a photographic camera of } 2 \text { megapixels. The } \\
\text { cost of the project is R\$ } 3 \text { million. Recently, one of } \\
\text { your competitors launched a superior mode, which is } \\
\text { lighter and has a photographic camera of } 5 \text { megapixels. } \\
\text { As director of the company, would you invest these R\$ } \\
3 \text { million? } \\
\text { Yes } \\
23.39 \%\end{array}$ & $\begin{array}{l}\text { Suppose you are the director of "Genérica } \\
\text { Telecomunicações S./A.", a company which } \\
\text { develops and produces cell phones. The engineering } \\
\text { department presented a proposal to develop a new } \\
\text { cell phone, which has a photographic camera of } 2 \\
\text { megapixels. This project will have a total cost of R\$ } \\
10 \text { million, whereas to date R } \$ 7 \text { million have } \\
\text { already been spent. Recently, one of your } \\
\text { competitors launched a superior model, which is } \\
\text { lighter and has a photographic camera of } 5 \\
\text { megapixels. As director of the company, would you } \\
\text { invest the R\$ } 3 \text { million missing to finish your } \\
\text { project? } \\
\text { Yes No } \\
59.23 \%\end{array}$ \\
\hline
\end{tabular}




\section{Chart 3: Third scenario questions}

This was the scenario with the greatest differential among the two different formulation, the smaller proportion of getting the questions right $(40.77 \%)$ being in questionnaire with sunk costs. The mean equality test reflects this, with a high degree of rejection of the null hypothesis.

Table 6: Mean equality test - scenario 3

\begin{tabular}{l|l|l|l}
\hline \multicolumn{1}{c|}{ Test } & \multicolumn{1}{|c|}{ Value } & \multicolumn{1}{c}{ Probability } \\
\hline Test t & 8.772640 & 0.0000 \\
Statistic F Anova & 76.95921 & Mean/Proportion & 0.0000 \\
\hline Questionnaire & Quantity & 0.766129 & Standard Deviation \\
\hline Without Sunk Costs & 248 & 0.407692 & 0.424147 \\
With Sunk Costs & 260 & 0.582677 & 0.492353 \\
Total & 508 & & 0.493603 \\
\hline
\end{tabular}

The test in logit model confirms the mean equality test, with lower probability of getting the problem right when this involves sunk costs.

Table 7: Logit regression - scenario 3

\begin{tabular}{l|l|l|l|l}
\hline \multicolumn{1}{c|}{ Variable } & \multicolumn{1}{c|}{ Coefficient } & \multicolumn{1}{c|}{ Std. Error } & \multicolumn{1}{c}{ z-Statistic } & \multicolumn{1}{c}{ Prob. } \\
\hline SUNKCOSTS & -1.560095 & 0.196041 & -7.958015 & 0.0000 \\
C & 1.186581 & 0.150015 & 7.909753 & 0.0000 \\
\hline Mean dependent var & 0.582677 & S.D. dependent var & 0.493603 \\
S.E. of regression & 0.460323 & Avg. log likelihood & -0.611520 \\
Sum squared resid & 107.2201 & McFadden R-squared & 0.099929 \\
Log likelihood & -310.6520 & LR statistic (1 df) & 68.97969 \\
Restr. log likelihood & -345.1419 & Probability (LR stat) & $1.11 \mathrm{E}-16$ \\
\hline
\end{tabular}

The logit model with the qualitative variable of right answers with sunk costs was also formulated to capture the effect of the respondents' characteristics.

Table 8: Logit regression - scenario 3 with sunk costs

\begin{tabular}{l|l|l|l|l}
\hline Variable & Coefficient & Std. Error & z-Statistic & Prob. \\
\hline MAN & -0.275892 & 0.233566 & -1.181214 & 0.2375 \\
LAW & -0.324219 & 0.391896 & -0.827308 & 0.4081 \\
COMPUTING & 0.977398 & 0.657104 & 1.487434 & 0.1369 \\
PHYSICS & 0.875547 & 0.367219 & 2.384264 & 0.0171 \\
MATHEMATICS & 0.869373 & 0.471291 & 1.844660 & 0.0651 \\
PSYICHOLOGY & -0.246887 & 0.398013 & -0.620298 & 0.5351 \\
AGE25TO30 & 0.108739 & 0.282178 & 0.385354 & 0.7000 \\
AGEABOVE30 & -0.286202 & 0.441862 & -0.647717 & 0.5172 \\
C & -1.291091 & 0.192606 & -6.703272 & 0.0000 \\
\hline Mean dependent var & 0.208661 & S.D. dependent var & 0.406752 \\
S.E. of regression & 0.404146 & Avg. log likelihood & -0.499065 \\
Sum squared resid & 81.50358 & McFadden R-squared & 0.025601 \\
Log likelihood & -253.5252 & LR statistic (8 df) & 13.32214 \\
Restr. log likelihood & -260.1863 & Probability (LR stat) & 0.101236 \\
\hline
\end{tabular}


The test in connection with the courses presented, in general, a not very conclusive result. The students of Physics and Mathematics presented a significant and positive result, which shows greater probability of these courses in relation to those related to the business area. The students of Law, Computing and Psychology did not show a statistically different result in relation to the base, formed by courses in Administration, Accounting, Economics and Production Engineering.

With respect to general questions, no result proved very significant. Even so, the gender presented an inverse sign of the previous problem, and the age ranges, the same signs.

\begin{tabular}{|c|c|}
\hline Questionnaire - With Sunk Costs & Questionnaire B - Without Sunk Costs \\
\hline $\begin{array}{l}\text { You have bought a ticket to go see a preview in the } \\
\text { cinema of a film expecting to see an interesting movie, } \\
\text { and paid for this ticket } \mathrm{R} \$ 10.00 \text {. You went to the } \\
\text { cinema expecting to watch an interesting movie. } \\
\text { Unfortunately none of your friends wanted to joint you. } \\
\text { After a few minutes of the film, you are let down and } \\
\text { noticed that it was not exactly what you had imagined. } \\
\text { Afterwards, you receive a message from one of your } \\
\text { friends on the cell phone, inviting you to join them to a } \\
\text { bar where everybody is together. Would you continue } \\
\text { to watch the movie? }\end{array}$ & $\begin{array}{l}\text { You subscribe to a newspaper and there was a } \\
\text { promotion which offered free tickets to the launch of } \\
\text { a new movie, and you won one of them. You went to } \\
\text { the cinema expecting to watch an interesting movie. } \\
\text { Unfortunately none of your friends wanted to joint } \\
\text { you. After a few minutes of the film, you are let } \\
\text { down and noticed that it was not exactly what you } \\
\text { had imagined. Afterwards, you receive a message } \\
\text { from one of your friends on the cell phone, inviting } \\
\text { you to join them to a bar where everybody is } \\
\text { together. Would you continue to watch the movie?? } \\
\text { Yes No }\end{array}$ \\
\hline $\begin{array}{lll}\text { Yes } & \text { No } & \\
& 31.05 \% & 68.95 \%\end{array}$ & $25 \%$ \\
\hline
\end{tabular}

\section{Chart 4: Fourth scenario questions}

Again, the problem that did not involve sunk costs presents a higher percentage of getting the answer right. However, the mean equality test does not reject the null hypothesis of equality due to the minimum level of significance considered (10\%).

Table 9: Mean equality test - scenario 4

\begin{tabular}{l|l|l|l}
\hline \multicolumn{1}{c|}{ Test } & \multicolumn{1}{c}{ Value } & \multicolumn{1}{c}{ Probability } \\
\hline Test t & 1.518904 & & 0.1294 \\
Statistic F Anova & 2.307071 & Mean/Proportion & 0.1294 \\
\hline Questionnaire & Quantity & 0.750000 & Standard deviation \\
\hline Without Sunk Costs & 260 & 0.689516 & 0.433848 \\
With Sunk Costs & 248 & 0.720472 & 0.463627 \\
Total & 508 & & 0.449209 \\
\hline
\end{tabular}

Again, the logit model confirms the mean equality test, and the probability differential, despite being negative, as expected, is not significant.

Table 10: Logit regression - scenario 4

\begin{tabular}{l|l|l|l|l}
\hline \multicolumn{1}{c|}{ Variable } & \multicolumn{1}{c|}{ Coefficient } & \multicolumn{1}{c|}{ Std. Error } & \multicolumn{1}{c}{ z-Statistic } & \multicolumn{1}{c}{ Prob. } \\
\hline SUNKCOSTS & -0.180010 & 0.118607 & -1.517701 & 0.1291 \\
C & 0.674490 & 0.084507 & 7.981480 & 0.0000 \\
\hline Mean dependent var & 0.720472 & S.D. dependent var & 0.449209 \\
S.E. of regression & 0.448632 & Avg. log likelihood & -0.590236 \\
Sum squared resid & 101.8427 & McFadden R-squared & 0.003832 \\
Log likelihood & -299.8400 & LR statistic (1 df) & 2.306704 \\
Restr. log likelihood & -300.9933 & Probability (LR stat) & 0.128817 \\
\hline
\end{tabular}


Lat, one tested a logit model with data from the four scenarios grouped, so as to measure the general effect of the sunk costs on the answers. The objective of a model in which the data of the different questionnaires are tested together is to filter the particularities of each questionnaire and test if, in general, the sunk costs are relevant as a source of cognitive bias, and if this bias is affected by the characteristics of the individuals, by their experience and knowledge of the subjects in the business areas.

Table 11: Logit regression - all the scenarios

\begin{tabular}{l|l|l|l|l}
\hline \multicolumn{1}{c|}{ Variable } & \multicolumn{1}{c|}{ Coefficient } & \multicolumn{1}{c|}{ Std. Error } & \multicolumn{1}{c}{ z-Statistic } & \multicolumn{1}{c}{ Prob. } \\
\hline SUNKCOSTS & -0.598730 & 0.095111 & -6.295061 & 0.0000 \\
C & 0.981280 & 0.070451 & 13.92863 & 0.0000 \\
\hline Mean dependent var & 0.660925 & S.D. dependent var & 0.473512 \\
S.E. of regression & 0.468941 & Avg. log likelihood & -0.630524 \\
Sum squared resid & 446.4085 & McFadden R-squared & 0.015452 \\
Log likelihood & -1281.225 & LR statistic (1 df) & 40.21659 \\
Restr. log likelihood & -1301.333 & Probability (LR stat) & $2.27 \mathrm{E}-10$ \\
\hline
\end{tabular}

The first test was restricted, with the objective of obtaining the probability differential of getting the problems right, in the presence of sunk costs. The result was satisfactory and of high significance. This indicates a probability $81.98 \%$ lower of getting the problems right when sunk costs are involved in the decision. This general result confirms the first hypothesis, of relevance of the cognitive bias caused by sunk costs.

The tests of characteristics of the respondents with the right answers to the problems with sunk costs presented only the students of Physics with probability differential significant in $41.1 \%$ more than students from the business area. Analyzing the signs, the students of other courses, with the exception of Psychology, presented a positive sign, which constitutes the opposite of what was expected. Even if it does not have any significance, this result supplies signs that the hypothesis that the students who study the methods of the financial decisions are less propense to the cognitive bias caused by sunk costs is not sustained.

Table 12: Logit regression - all scenarios with sunk costs

\begin{tabular}{l|l|l|l|l}
\hline \multicolumn{1}{c|}{ Variable } & \multicolumn{1}{c|}{ Coefficient } & \multicolumn{1}{c|}{ Std. Error } & \multicolumn{1}{c}{ z-Statistic } & \multicolumn{1}{c}{ Prob. } \\
\hline MAN & -0.060695 & 0.101712 & -0.596735 & 0.5507 \\
LAW & 0.012810 & 0.154414 & 0.082956 & 0.9339 \\
COMPUTING & 0.043406 & 0.340994 & 0.127293 & 0.8987 \\
PHYSICS & 0.343871 & 0.176945 & 1.943372 & 0.0520 \\
MATHEMATICS & 0.099340 & 0.238888 & 0.415841 & 0.6775 \\
PSYCHOLOGY & -0.174791 & 0.168765 & -1.035708 & 0.3003 \\
AGE25TO30 & -0.130107 & 0.128495 & -1.012545 & 0.3113 \\
AGE ABOVE30 & -0.061168 & 0.176574 & -0.346413 & 0.7290 \\
C & -0.816960 & 0.085345 & -9.572425 & 0.0000 \\
\hline Mean dependent var & 0.297244 & S.D. dependent var & 0.457157 \\
S.E. of regression & 0.457274 & Avg. Log likelihood & -0.606829 \\
Sum squared resid & 423.0074 & McFadden R-squared & 0.002765 \\
Log likelihood & -1233.076 & LR statistic (12 df) & 6.837314 \\
Restr. Log likelihood & -1236.495 & Probability (LR stat) & 0.554283 \\
\hline
\end{tabular}


The gender and age characteristics were not significant. The signs, however, were all negative. This demonstrates that, for the sample, the men and respondents above 25 years old got questions right less than the women and youngsters below 25 .

\section{CONCLUSION}

The objective of the study was to investigate if the undergraduate student of the business area is less susceptible to the sunk cost effect than students from other areas. Moreover, characteristics such as gender and age influenced in the decision process involving the sunk cost effect.

Analyzing the set of answers, it was not possible to notice susceptibility significantly lower by students of the business area to the sunk cost effect. What occurred was exactly the opposite, the students of Physics were less susceptible than the students of Administration, Accounting, Economics and Production Engineering. In the case of problem 3, which presents a typically entrepreneurial scenario, the Mathematics students also had better performance. Quite a similar problem to this one was used in the research conducted by Tan and Yates (1995). In this case, the analysis of the results indicated that the Accounting students were less propense to consider sunk costs in decision-making. These authors reached the conclusion that, due to the fact of the problem using a typical scenario from the business area, the students would more inclined to use the knowledge acquired in the classroom and disregard irrelevant costs.

The discrepancy between the results of the two researches permits to consider this problem as open. After all, upon typical problems of the business are being presented (which involve sunk costs), do students of Accounting, Economics and Production Engineering take more rational decision than students from other areas? If business students had more propensity to the sunk cost effect, it will be simple to attribute this to the teaching of management and cost accounting. But, if precisely the opposite happens, the explanations will be less evident and deserve a closer investigation due to their consequences for the teaching of accounting and the decision making process.

In the two cases in which the sunk cost effect did not occur, the reason for this can lie in the greater relevance of other factors analyzed by the students. In the first question, which involved the sale of car, this can be explained by the comfort provided by the car, in addition to its value as a status symbol. It should be observed that, with or without sunk costs, approximately half of respondents did not wish to sell the car - even spending less on the bus than with the maintenance of the vehicle. If a significant portion of persons prefers to have a marginal cost of at least $\mathrm{R} \$ 100$ to go to university driving their own car, then the decision to keep the vehicle can have origin in considerations that go beyond the financial aspect, so that the existence of sunk costs was not even taken into consideration by a large portion of respondents.

These observations suggest the hypothesis that irrelevant information - irrecoverable costs - is taken into consideration only when there are no other more salient data to support the decision making. The confirmation of this suspicion, naturally, requires a specific study for this purpose, involving questions with and without additional information. Different types of information can also trigger different reactions: appeals of an emotional order may have a different effect of technical data with respect to the problem. This can be noticed in the third question, which brought information on the cell phone model, being developed. Even so, the sunk cost effect was quite accentuated. 
This study used questionnaires applied in the classroom. As stated in the methodology, this is a limitation, the next research could physically separate students into two groups, preventing one from noticing the existence of two questions. It should be stressed also that the results obtained here do not permit one to reach a conclusion on the causes of the differences observed among the courses, it would be necessary, for this, to interview students individually, asking them about the reasoning used to reach their decision.

\section{REFERENCES}

ALLAIS, Maurice. Le comportement de l'homme rationnel devant le risque: critique des postulats et axiomes de l'ecole americaine. Econometrica, v. 21, n. 4, p. 503-546, out. 1953. ARKES, Hal R.; AYTON, Peter. The sunk cost and Concorde effects: are humans less rational than lower animals? Psychological Bulletin, v. 125, n. 5, p. 591-600, set. 1999.

ARKES, Hal R; BLUMER, Catherine. The psychology of sunk costs. Organizational Behavior and Human Decision Process, v. 35, p. 124-140, 1985.

ARKES, Hal R; HUTZEL, Laura. The role of probability of success estimates in the sunk costs effect. Journal of Behavioral Decision Making, v. 13, p. 295-603, 2000.

BAKER, Kent H.; NOFSINGER, John R. Psychological biases of investors. Financial Services Review, Atlanta, v. 11, n. 2, p. 97-117, 2002.

DOMINGOS, Naiára Tavares; SOUZA, Francisca Aparecida de; SILVA, César Augusto Tibúrcio. Efeito do Custo Perdido: a influência do custo perdido na decisão de investimento. In: I Congresso ANPCONT, 2007, Gramado - RS, Anais... 2007. p. 1-11.

GUJARATI, Damodar N. Econometria Básica. 3. ed. São Paulo: Pearson Makron Books, 2000.

HEATH, Chip. Escalation and de-escalation of commitment in response to sunk costs: the role of budgeting in mental accounting. Organizational Behavior and Human Decision Processes, v. 62, n. 1, p. 38-54, abr. 1995.

HIRSHLEIFER, David. Investor psychology and asset pricing. The Journal of Finance, v. 56, n. 4, p. 1533-1597, ago. 2001.

JANG, Dongsuk; MATTILA, Anna S.; BAI, Billy. Restaurant membership fee and customer choice: the effects of sunk cost and feelings of regret. Hospitality Management, v. 26, p. 687-697, 2007.

KAHNEMAN, Daniel. Maps of bounded rationality: Psychology for behavioral economics. The American Economic Review, v. 93, n. 5, p. 1449-1475, 2003.

KAHNEMAN, Daniel; TVERSKY, Amos. Prospect theory: an analysis of decision under risk. Econometrica, v. 47, n. 2, p. 263-290, mar. 1979.

KRITZMAN, Mark. What practitioners need to know about utility? Financial Analysts Journal, v. 48, n. 3, p. 17-20, maio/jun. 1992.

MCELHINNEY, David; PROCTOR, Tony. Concept of entrapment and decision-making. Management Decision, v. 43, n. 2, p. 189-202, fev. 2005.

MURCIA, Fernando Dal-Ri; BORBA, José Alonso. Um estudo empírico sobre os efeitos dos sunk costs no processo decisório dos indivíduos: evidências dos estudantes de graduação de uma universidade federal. UnB Contábil, Brasília, v. 9, n. 2, p. 223-247, jul./dez. 2006.

RAIFFA, Howard. Decision analysis: introductory lectures on choice under uncertainty. Mendo Park: Addison-Wesley, 1968. 
SCHAUBROECK, John; DAVIS, Elaine. Prospect Theory predictions when escalation is not the only chance to recover sunk costs. Organizational Behavior and Human Process, v. 57, p. 59-82, 1994.

TAN, Hun-Tong; YATES, J. Frank. Sunk cost effects: the influences of instruction and future return estimates. Organizational Behavior and Human Decision Processes, v. 63, n. 3, p. 331-319, set. 1995.

THALER, Richard. Toward a positive theory of consumer choice. Journal of Economic Behavior \& Organization, v. 1, n. 1, p. 39-60, mar. 1980.

TVERSKY, Amos. Intransitivity of preferences. Psychological Review, v. 76, n. 1, p. 31-48, jan. 1969.

TVERSKY, Amos; KAHNEMAN, Daniel. Judgment under uncertainty: heuristics and biases. Science, v. 185, n. 4157, p. 1124-1131, set. 1974.

TVERSKY, Amos; KAHNEMAN, Daniel. The framing of decisions and the psychology of choice. Science, v. 211, n. 4481, p. 453-458, jan. 1981.

WEBLEY, Paul; PLAISIER, Zarrea. Mental accounting in childhood. In: Conference On Subjective Probability, Utility And Decision Making, 16., 1997, Leeds - UK. Anais... 1997.

ZEELENBERG, Marcel; DIJK, Eric van. A reverse sunk cost effect in risky decision making: Sometimes we have too much invested to gamble. Journal of Economic Psychology, v. 18, n. 6, p. 677-691, nov. 1997. 